\title{
FACTORS ASSOCIATED WITH NEONATAL ASPHYXIA: A PATH ANALYSIS EVIDENCE FROM NGANJUK, EAST JAVA
}

\author{
Remita Yuli Kusumaningrum(1), Bhisma Murti'), Hanung Prasetya') \\ 1) Masters Program in Public Health, Universitas Sebelas Maret \\ 2) Study Program in Acupuncture, School of Health Polytechnics, \\ Ministry of Health Surakarta
}

\begin{abstract}
Background: Asphyxia neonatorum is a condition that occurs when a newborn infant does not get enough oxygen during the birth process. Asphyxia neonatorum is a leading cause of brain damage and death in infants worldwide. An estimated 900,000 infants die each year around the world due to asphyxia neonatorum, with the majority of these deaths occurring in developing countries. This study aimed to investigate factors associated with neonatal asphyxia in Nganjuk, East Java.

Subjects and Method: A case control study was carried out at Nganjuk Hospital, East Java. A sample of 150 infants was selected for this study by simple random sampling. The dependent variable was asphyxia. The independent variables were gender, low birth weight, prematurity, and pre-eclampsia. The data were taken from medical record. The data were analyzed by path analysis.

Results: The risk of birth asphyxia increased with male $(b=0.76 ; 95 \% \mathrm{CI}=-0.02$ to $1.54 ; \mathrm{p}=0.057)$, low birth weight $(\mathrm{b}=1.84 ; 95 \% \mathrm{CI}=1.01$ to $2.67 ; \mathrm{p}<0.001)$, and prematurity $(\mathrm{b}=1.40 ; 95 \% \mathrm{CI}=0.58$ to $2.22 ; \mathrm{p}=0.001)$. The risk of prematurity increased with pre-eclampsia $(b=0.89 ; 95 \% \mathrm{CI}=0.20$ to $1.58 ; \mathrm{p}=0.012)$.
\end{abstract}

Conclusion: The risk of birth asphyxia increases with male, low birth weight, and prematurity. The risk of prematurity increases with pre-eclampsia.

Keywords: asphyxia, low birth weight, prematurity, gender, pre-eclampsia

\section{Correspondence:}

Remita Yuli Kusumaningrum. Masters Program in Public Health, Universitas Sebelas Maret, Jl. Ir. Sutami No. 36 A, Surakarta 57126, Central Java.

Email: remita.yuli@gmail.com. Mobile: 081231871222 